\title{
Histidinaemia
}

\section{Study of Relation Between Clinical and Biological Findings in 7 Subjects}

\author{
B. G. R. NEVILLE, A. BENTOVIM, BARBARA E. CLAYTON, and JEAN SHEPHERD \\ From The Hospital for Sick Children and the Institute of Child Health, London
}

\begin{abstract}
Neville, B. G. R., Bentovim, A., Clayton, B. E., and Shepherd, J. (1972). Archives of Disease in Childhood, 47, 190. Histidinaemia: study of relation between clinical and biochemical findings in 7 subjects. Seven subjects with raised plasma histidine and low skin histidase levels (histidinaemia) are described: 4 were severely retarded, 2 showing in addition features of an early infantile psychosis (autism); 3 were of normal intelligence. There were no biochemical differences between the two groups.

In view of these findings and a study of patients reported in the literature, attention is drawn to the difficulty in making a decision about treatment of a neonate detected by screening and shown to have the biochemical features of histidinaemia. The natural history of the condition is further examined, particularly the question of deterioration at time of seizures or infection.
\end{abstract}

In 1961, Ghadimi, Partington, and Hunter described two sisters with a raised plasma histidine level: a 3-year-old with marked speech delay but normal non-verbal IQ, and a 4-year-old who was then entirely normal. They commented, 'the relationship between the abnormal histidine metabolism and the speech defect is not clear'. In general, the biochemical findings in these and subsequent patients have included increased histidine in plasma and urine, raised urinary excretion of metabolites of histidine, an absence of histidine ammonia lyase (histidase) activity in the skin, and an abnormal histidine tolerance curve. Though this biochemical abnormality has been designated 'histidinaemia' (Auerbach et al., 1962), the problem of its significance remains.

Clinical data on 42 published subjects including the 7 reported in the present paper have been tabulated. Table I summarizes 28 subjects with intelligence within the normal range (i.e. IQ $>80$ ) of whom 7 had defective speech. Table II gives similar data on those who were mentally retarded. 7 reported subjects are not included since insufficient biochemical data or information on intellectual status were given (Gerritsen, 1964, Cases 2 and 3; Davies and Robinson, 1963; Shaw et al., 1963;

Received 13 September 1971.
La Du, 1966, Cases 10, 11, and 12). 3 retarded sibs (Woody, Snyder, and Harris, 1965) have also not been included since plasma histidine was only marginally raised and skin histidase was present.

This paper describes a further 7 subjects with raised levels of plasma histidine, and examines the significance of this finding with particular reference to the use of a low histidine diet in infants found to have this biochemical abnormality on routine screening. In our own patients, raised plasma histidine is defined as a value greater than $5 \mathrm{mg} /$ $100 \mathrm{ml}$ in both a random and a fasting sample.

Details of histidine and urocanic acid levels in skin have already been reported on some of these patients by Whitfield and Shepherd (1970). Their Families 1 and 2 correspond to those in this paper and Family 3 of their communication is the family of Subject 5.

\section{Subjects}

Patients and their families. Members of two families were studied in detail after one child in each had been admitted to The Hospital for Sick Children for the investigation of abnormalities of behaviour and mental retardation. Studies on a further 2 retarded patients and 1 patient with normal intelligence and raised plasma histidine are also described. 
TABLE I

Summary of 28 Subjects of Normal Intelligence with Raised Plasma Histidine

16 subjects $\nmid$ were completely normal while the 12 subjects listed had speech problems, seizures, or 'low normal' intelligence.

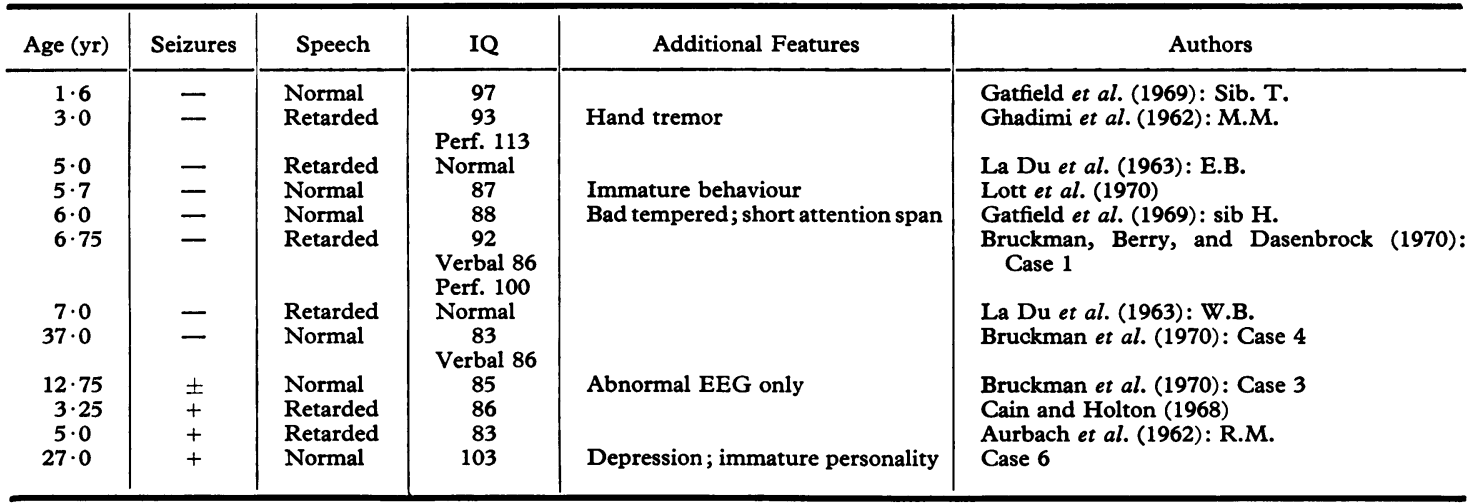

†Auerbach, Di George, and Carpenter (1967). Do.R

Auerbach et al. (1967). Ro.R

Ghadimi et al. (1961). E.M.

Lott, Wheelden, and Levy (1970).

Auerbach et al. (1967). Ma. S.

Lott et al. (1970).

Auerbach et al. (1967). De R.

Control subjects. Loading tests with histidine were performed in 4 men and 3 women (18-34 years) who were members of the laboratory staff. 2 boys and 2 girls aged 1 to 2.5 years, and 5 boys and 5 girls aged 7 to 15 years were also loaded. They were all below the third centile for height and were inpatients in whom the serum growth hormone response to Bovril was being evaluated (Jackson, Grant, and Clayton, 1968); histidine was administetered in the Bovril. This control situation, though not ideal, was the only one available to us which seemed justified. Bovril contains only small amounts of free amino acids. Details of the control
Gilman and Howell (1969).

Gatfield et al. (1969). Sib C.

Auerbach et al. (1967). G.O.S.

Rosenblatt, Mohyuddin, and Scriver (1970).

Auerbach et al. (1967). Ge. S.

Bruckman et al. (1970). Case 5

Bruckman et al. (1970). Case 6

Cases 2 and 4

subjects for skin histidase and urocanic acid have been reported previously (Whitfield and Shepherd, 1970).

\section{Case Reports on Subjects with Raised Plasma Histidine}

The index patients were Cases $1,3,5,6$, and 7 . The sibs of Cases 1 (Family 1) and 3 (Family 2) were then studied in some detail and raised plasma histidine was found in one sib in each of them (Cases 2 and 4).

Case 1 (1f). A 3-year-old girl was admitted because

TABLE II

Summary of 14 Mentally Retarded Subjects with Raised Plasma Histidine

\begin{tabular}{|c|c|c|c|c|}
\hline Age (yr) & Seizures & IQ & Additional Features & Authors \\
\hline $\begin{aligned} 3 \cdot 0 \\
3 \cdot 0 \\
4 \cdot 0 \\
8 \cdot 5 \\
10 \cdot 0 \\
13 \cdot 0 \\
4 \cdot 5 \\
13 \cdot 5 \\
3 \cdot 5 \\
5 \cdot 0 \\
8 \cdot 9 \\
13 \cdot 0 \\
4 \cdot 0 \\
24 \cdot 0\end{aligned}$ & $\begin{array}{c}= \\
= \\
= \\
= \\
= \\
++ \text { fatal } \\
+ \\
+ \\
+ \\
+ \\
+\end{array}$ & $\begin{array}{c}\text { Retarded } \\
\text { Retarded } \\
60 \\
\\
74 \\
\text { Retarded } \\
45 \\
\text { Marked retardation } \\
\text { Marked retardation } \\
\text { Marked retardation } \\
23 \\
70 \\
\text { Probably retarded } \\
<20 \\
\text { Marked retardation }\end{array}$ & $\begin{array}{l}\text { Early infantile psychotic disorder } \\
\text { Early infantile psychotic disorder } \\
\text { Cleft lip and palate } \\
\text { Hyperactive deterioration with epilepsy } \\
\text { Quadriplegic cerebral palsy }\end{array}$ & $\begin{array}{l}\text { Gerritsen (1964) } \\
\text { Wadman et al. (1967) } \\
\text { La Du (1966) } \\
\\
\text { Bruckman et al. (1970) Case } 2 \\
\text { Wadman et al. (1967) } \\
\text { Clarance and Bowman (1966) } \\
\text { Case } 5 \\
\text { Case } 3 \\
\text { Corner et al. (1968) } \\
\text { Gatfield et al. (1969) } \\
\text { Gilman and Howell (1969) } \\
\text { Wadman et al. (1967) } \\
\text { Case } 1 \\
\text { Case } 7\end{array}$ \\
\hline
\end{tabular}


her development was slow. She was the fourth child born to unrelated parents, the pregnancy and delivery at 38 weeks being normal. The birthweight was $3650 \mathrm{~g}$, and there was no neonatal asphyxia. She was unusually quiet and from birth had to be woken to be fed. From the fourth day episodes of stiffening of the trunk and limbs were observed until by the 12th day they were recognized as major seizures. Prolonged fits continued at a frequency of 10-30 observed in a day and were unaffected by phenobarbitone. Between the ages of 2 and 4 weeks the head circumference rose from $37 \mathrm{~cm}$ to $39 \mathrm{~cm}$. Subdural taps and lumbar punctures failed to show evidence of subdural haematoma or meningitis and she was transferred to the neurosurgical unit of this hospital at 4.5 weeks. The anterior fontanelle was tense but no other abnormalities were noted on physical examination. Skull $x$-rays showed a moderate degree of suture separation. An EEG was grossly abnormal with multifocal discharges. Fasting serum calcium and food sugar were normal but no amino acid studies were performed. Lumbar air encephalography showed normal basal cisterns, no air over the cortex, and a normal ventricular system. It was considered at that time that the rise in head circumference was attributable to cerebral oedema following prolonged frequent seizures. Seizures continued until the age of 18 months. Phenobarbitone and phenytoin were given throughout this period.

Her development was much delayed. At 3 years she required total care and was unable to sit or support her head. She was not responding socially except for occasional smiles and had no speech. On examination she was a quiet passive girl with light brown hair, a fair skin, and brown eyes. She could just lift her head from the horizontal but there was moderate head lag. She could get from back to front only. Slow writhing movements were occasionally noted in the arms often associated with neck retraction and a slow inappropriate smile. Head circumference was $48.5 \mathrm{~cm}$. The Moro reflex was absent. A moderate asymmetric tonic neck response was present and no saving reactions were demonstrable. The cranial nerves including fundi were essentially normal. There was a rigidity in all muscle groups in the arms and proximally in the legs, and deep tendon reflexes were pathologically brisk. She therefore had signs of mixed athetoid and spastic cerebral palsy with gross developmental retardation.

Routine haematological investigations were normal; $x$-rays of skull, spine, and hips were also normal at that stage. Random plasma histidines were $10 \mathrm{mg}$ and $15 \mathrm{mg} / 100 \mathrm{ml}$ and a 24-hour urine contained a gross excess of histidine.

Case 2 (1e). This $5 \frac{1}{2}$-year-old sister of Case 1 (1f) was clinically normal. Further details are given later.

Case 3 (2e). A 12-year-old boy was admitted for investigation of slow development and abnormal behaviour. He was the fourth child born to unrelated healthy parents. Family details are given later. The pregnancy, term delivery, and neonatal period were normal with a birthweight of $3800 \mathrm{~g}$. Breast feeding for the first three months was uneventful. His mother reports that he was affectionate and smiled and laughed appropriately. He sat unaided at 6 months and walked alone at 14 months. At 1 year he was admitted to hospital for 10 days with a lower respiratory infection and oxygen was required. No deterioration was noted at that time but though motor, bowel, and bladder control developed normally, language development was poor. Mechanical tasks were performed efficiently but speech was limited to echoing one or two words and was rarely spontaneous.

By 3 years he was becoming increasingly withdrawn. He attended normal school at 4.5 years but was unmanageable on account of overactivity, screaming, head banging, and failure to communicate. At 5.5 years his IQ was 35 (Terman Merrill) and day care was provided at a subnormality hospital with periods as an inpatient when his parents were unable to cope. Speech remained limited with marked echolalia. He related poorly to other children, his behaviour was stereotyped and hyperactive, and when frustrated he responded with head banging and hand biting. There was a poor response to phenothiazines. $\mathrm{He}$ was interested in music and could pick out favourite records. He had no seizures.

Over the years he had gradually become less active, but was occasionally underactive. Spontaneous vocalization generally lessened; and he remained abnormally fearful, anxious, and self-isolated, but a little more affectionate.

He was a thin, pale-looking boy. Physical examination revealed no abnormality, apart from some stiffness of the shoulders, which resolved with physiotherapy. His mental state was of a boy internally preoccupied, withdrawn, and fleetingly suspicious, with brief periods of hyperactivity and long periods of immobility. $\mathrm{He}$ played with balloons which he blew up and burst to the accompaniment of much laughing and shouting and was more interested in such objects than people. He could passively obey simple commands and pointed to many named objects. Prominent mannerisms were grinning, plucking at his neck, and masturbating. He occasionally showed socially inappropriate overaffection or aggression, but usually showed marked gaze avoidance and aloofness.

Psychological testing revealed no abilities above a level of 4 to 5 years; verbal comprehension was at about a level of 3.5 years but speech was virtually absent. His social comprehension was much limited and he followed instructions automatically without any idea of their relevance. There was a degree of apparently purposeful withdrawal, and co-operation was difficult to maintain.

In summary, this severely mentally retarded boy showed the features of the late stage of an early-onset infantile psychosis (autism) (Rutter, Greenfield, and Lockyer, 1967), emerging from a state of autistic interpersonal relations showing distorted language development with echolalia persisting, abnormal motor stereo- 
types, mannerisms, and ritualistic interests. There has been no evidence of further deterioration in level of mental functioning over the past 5 years. Routine investigations including skull $x$-rays and EEG showed no abnormality, except for amino acid studies which showed a random plasma histidine of $15 \mathrm{mg} / 100 \mathrm{ml}$.

Case 4 (2d). The 18-year-old sister of Case 3 (2e) was clinically normal. Further details are given later.

Case 5. A $4 \frac{1}{2}$-year-old girl was admitted for investigation of abnormal behaviour and loss of skills.

She was the fourth of five children born to healthy unrelated parents. There were several respiratory infections during pregnancy but delivery at term was normal and her birthweight was $3625 \mathrm{~g}$. She appeared normal during the neonatal period. She was artificially fed, and at 3 weeks solids were introduced and taken well. She smiled at 8 weeks, sat alone at 8 months, and walked at 12 months. She repeated words at 8 months and was reported to use phrases and short sentences constructively by 2 years. She fed herself by 2 years and her parents considered her development normal up to that time. Her mother however described her as different from her sibs, unpredictable, and occasionally aggressive for no apparent reason. At 2 years 3 months she was separated briefly from her mother and then became ill for 3 weeks with 'influenza'. She appeared delirious with high fever and lost weight in that time. After this illness she regressed: she stopped talking, became restless, destructive, and noisy, and began to rock. Episodes of screaming occurred, often accompanied by jerking of the head. She seemed insensitive to pain and danger and laughed in a bizarre fashion apparently in response to inner impulses. Her parents felt out of contact with her and found her defiant and provocative. She had no seizures. No abnormalities were noted on neurological examination. She was a delicately featured blond-haired girl, with graceful, athletic movements and hyperactive level of behaviour. There was considerable determination in her attempts to run around the ward and out of it, with rage reactions following attempts to frustrate her and change the direction of activity. Though there was occasional eye-to-eye contact made with smiling, she avoided gaze for most of the time and even hid her eyes. A number of motor mannerisms were noted-whole body rocking, tongue clicking and sterotypes, touching cracks in the door, corners of the room, and showing little interest in play material apart from those which fitted in each other. She was found lying curled up in the sink. No speech was noted and she did not respond to body contact. She made no social contact and her eyes moved restlessly from one object to another. A psychological assessment showed a wide scatter of abilities with very low social and verbal skills and some near-normal manipulative skills. Routine haematological investigations and an EEG were normal. Random plasma histidine was $10 \mathrm{mg} / 100 \mathrm{ml}$.

In summary, this child showed the features of an early infantile psychosis (autism) with an unusual onset in that development was probably normal until 2 years. She was functioning at severely subnormal level.

Case 6. A woman of 27 of whom some details have been given in a previous communication on maternal histidinaemia (Neville et al., 1971) was admitted to the National Hospital for Nervous Diseases. She was the second child born to unrelated parents. Her brother was mildly retarded and had epilepsy and histidinaemia. The pregnancy, delivery, and neonatal period were normal. Her development was reported to be normal though she tended to be active and aggressive. She made average progress at a normal school. Bilateral dislocation of the patellae was treated surgically at 6 years. From the age of 16 years she had infrequent major seizures which were treated with phenobarbitone and phenytoin, and four episodes of depression requiring psychiatric admission, and in two of them an overdose of anticonvulsant drugs was taken. She has remained excitable and has an immature personality disorder. She has had many employment and matrimonial problems. At 21 using the W.A.I.S., a verbal IQ of 98 and performance IQ of 103 was obtained. Physical examination revealed a minimal left-sided pyramidal deficit.

Case 7. This man aged 24 years had been in a long-term mental subnormality hospital from the age of 5 years. Details of his early history have been obtained from records. He was the third child born to unrelated parents after a pregnancy of 42 weeks and no family studies have yet been performed. $\mathrm{He}$ walked at 15 months and began to say single words at 15 to 16 months. $\mathrm{He}$ is reported to have regressed at the age of 2 with an episode of tonsillitis, losing speech permanently and walking temporarily. As a small child he was 'very nervous', restless, active, and destructive and required constant care. He had no speech but indicated simple needs by gesture and required help with feeding and dressing. Verbal comprehension was impaired. His urine tested in 1956 when he was about 11 gave a greenish-brown colour with ferric chloride reaction, but further tests for phenylketonuria were negative. His very limited ability to communicate had been lost gradually over a period of years and though he remained physically strong, active, destructive, and able to walk, he has required total care. During the previous 6 months he had had 3 major seizures and was being treated with phenytoin.

$\mathrm{He}$ was grossly retarded and non-communicating, making continuous stereotyped utterances, frequently hyperventilating. Physical examination (including full neurological examination) showed no abnormality.

There is some evidence of this man possibly showing some features of the late stage of an early infantile psychosis (autism) with severe retardation.

\section{Family Studies}

Psychological testing was performed without prior knowledge of the biochemical findings.

Family 1. The parents of Case 1 were not tested 


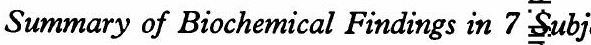

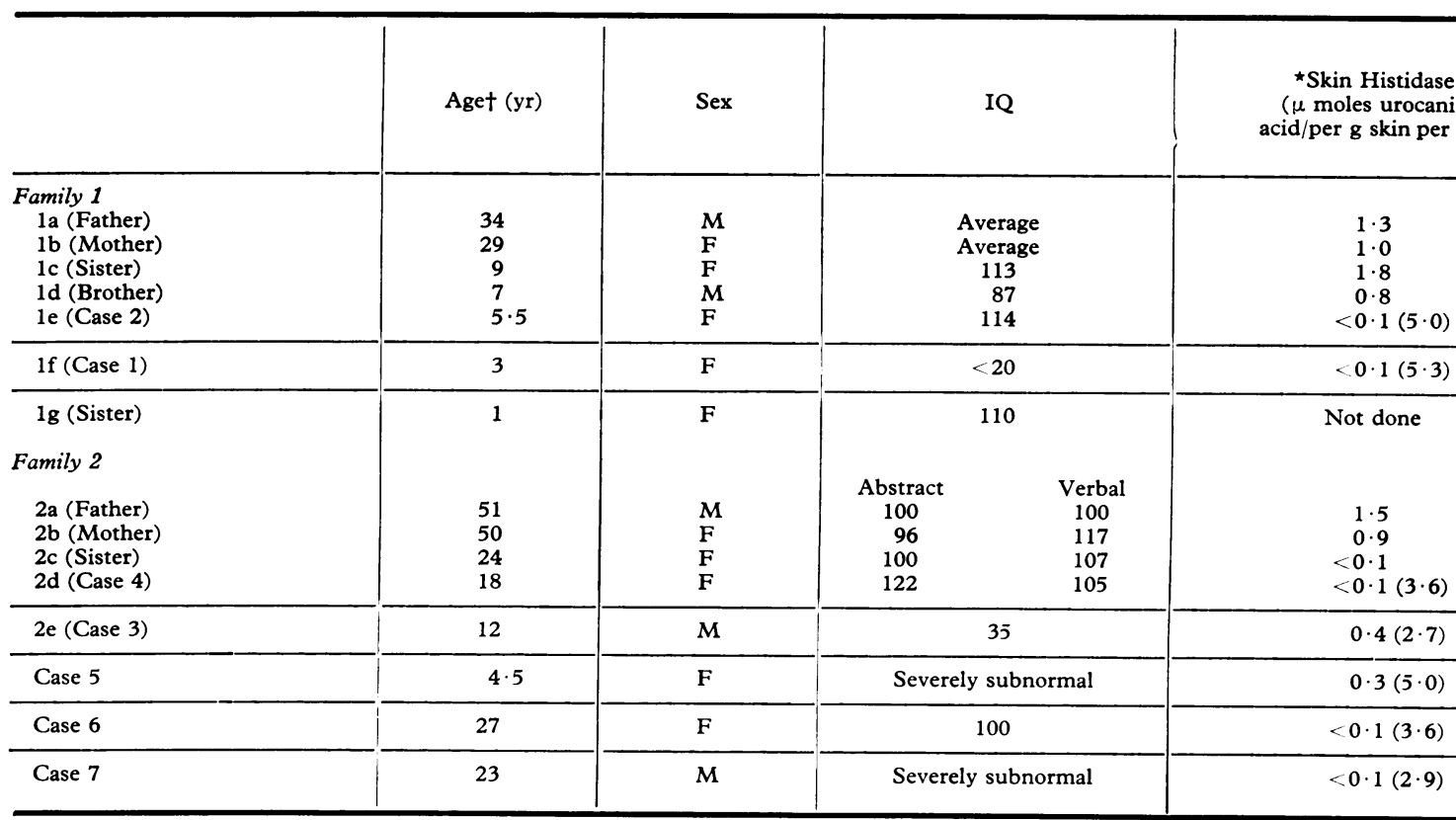

†Age at which the study was begun; investigations were spread over several months.

$\star$ Means for histidase and urocanic acid appropriate to age and sex in brackets (from Whitfield and Shepherd, 1970).

but appeared to be of average ability and no neurological disease was apparent. Case 1 had 3 sisters and 1 brother. Results of the study are shown in Table III. Psychological assessment (Mr. David Buick) showed problems only in the boy (1d) who had a lower score. $\mathrm{He}$ was quieter and less assertive than his sisters and had particular difficulty with the verbal aspects of the test which required more abstract thought. His fasting plasma histidine was not raised nor was skin histidase deficient but his non-fasting plasma histidine was

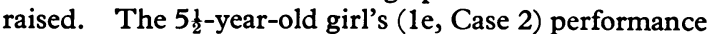
was consistently that of a child of bright normal intelligence. She progressed at school but was rather difficult to handle and tended to sulk or seek attention. None of these problems was severe and they were occurring in a family setting of considerable stress. Retesting 14 months later at 6 years and 8 months gave: verbal scale IQ 108 , performance scale IQ 125 , and fullscale IQ 119. On this occasion she was quiet and inhibited. She was reticent to give her opinion and needed a great deal of encouragement to get a response. It was felt that this was the main reason for the discrepancy between verbal and performance scales on the W.I.S.C. She showed a raised level of plasma histidine and a deficiency of skin histidine. No abnormalities of any kind were observed in $1 \mathrm{c}$ and $1 \mathrm{~g}$.

Family 2. The parents of Case 3 were of average ability and had no evidence of neurological disease.
The first three pregnancies resulted in miscarriages and details of the four live births (which included 3) are shown in Table III. Though no clinical abnormalities were found in his sisters $2 c$ and $2 d$, one of them (2d 4) showed raised plasma histidine levels.

\section{Biochemical Methods}

Oral histidine loading test. Subjects were fasted overnight, with the exception of Family 2 who had tinned peaches for breakfast 5 hours before the load as they had a long journey to the hospital, and the control children who were fasted for only 6 hours before the Bovril test. After an initial blood sample had been taken, L-histidine monohydrochloride monohydrate (KochLight laboratories Ltd.) equivalent to $0.1 \mathrm{~g}$ histidine/ $\mathrm{kg}$ was given dissolved in water and flavoured with fruit juice. $10 \mathrm{~g}$ glucose were given with the histidine and again 2 and 4 hours after the load. Capillary blood obtained by finger-prick was collected into heparin hourly for 5 hours after the load ( $2 \frac{1}{2}$ hours only for the control children). Subjects were encouraged to drink moderate amounts of water during the test to give a good urine flow. No urine was collected in the control children. In the other subjects urine samples were collected into merthiolate before and at hourly intervals for 5 hours after the load but when this was impossible any urine passed was collected. 5-hour urine collection was used because of problems in collect- 
Raised Plasma Histidine and Families

\begin{tabular}{|c|c|c|c|c|c|c|c|c|}
\hline \multirow{3}{*}{$\begin{array}{l}\text { ^Skin } \\
\text { Urocanic Acid } \\
\mu \text { moles } / g \text { skin })\end{array}$} & \multicolumn{7}{|c|}{ Plasma Histidine $(\mathrm{mg} / 100 \mathrm{ml})$} & \multirow{3}{*}{$\begin{array}{l}\text { Urinary Histidine } \\
\text { ( } \mathrm{mg} / \mathrm{kg} \text { body weight } \\
\text { in } 5 \mathrm{hr} \text { after load) }\end{array}$} \\
\hline & \multirow{2}{*}{ Random } & \multirow{2}{*}{ Fasting } & \multicolumn{5}{|c|}{ Hours After Load } & \\
\hline & & & 1 & 2 & 3 & 4 & 5 & \\
\hline $\begin{array}{l}33 \cdot 4 \\
24 \cdot 8 \\
38 \cdot 1 \\
34 \cdot 0 \\
7 \cdot 8(71 \cdot 7)\end{array}$ & $\begin{array}{r}4 \cdot 0 \\
3 \cdot 0 \\
3 \cdot 0 \\
5 \cdot 0 \\
12 \cdot 0\end{array}$ & $\begin{array}{l}1 \cdot 8 \\
2 \cdot 0 \\
1 \cdot 9 \\
6 \cdot 0\end{array}$ & $\begin{array}{r}6 \cdot 9 \\
5 \cdot 9 \\
5 \cdot 4 \\
11 \cdot 3\end{array}$ & $\begin{array}{r}7 \cdot 9 \\
6 \cdot 0 \\
6 \cdot 3 \\
13 \cdot 2\end{array}$ & $\begin{array}{c}\text { Not done } \\
8 \cdot 0 \\
6 \cdot 6 \\
5 \cdot 2 \\
12 \cdot 7\end{array}$ & $\begin{array}{r}5 \cdot 2 \\
4 \cdot 8 \\
4 \cdot 3 \\
12 \cdot 9\end{array}$ & $\begin{array}{r}5 \cdot 3 \\
4 \cdot 2 \\
3 \cdot 5 \\
12 \cdot 8\end{array}$ & $\begin{array}{l}5 \cdot 2 \\
7 \cdot 1 \\
5 \cdot 0 \\
8 \cdot 8\end{array}$ \\
\hline $5 \cdot 3(75 \cdot 4)$ & $15 \cdot 0$ & $5 \cdot 1$ & $9 \cdot 0$ & $10 \cdot 3$ & $11 \cdot 4$ & $7 \cdot 3$ & $9 \cdot 2$ & $4 \cdot 3$ \\
\hline Not done & $2 \cdot 0$ & $0 \cdot 8$ & $4 \cdot 2$ & $4 \cdot 0$ & $3 \cdot 2$ & - & $2 \cdot 0$ & $1 \cdot 0$ \\
\hline $\begin{array}{l}23 \cdot 4 \\
26 \cdot 0 \\
23 \cdot 2 \\
10 \cdot 8(41 \cdot 0)\end{array}$ & $\begin{array}{l}2 \cdot 4 \\
2 \cdot 6 \\
2 \cdot 7 \\
5 \cdot 2\end{array}$ & $\begin{array}{l}3 \cdot 9 \\
4 \cdot 0 \\
2 \cdot 8 \\
6 \cdot 2\end{array}$ & $\begin{array}{l}14 \cdot 0 \\
18 \cdot 8 \\
19 \cdot 0\end{array}$ & $\begin{array}{r}- \\
8 \cdot 8 \\
8 \cdot 3 \\
16 \cdot 2\end{array}$ & $\begin{array}{r}10 \cdot 6 \\
7 \cdot 4 \\
10 \cdot 0 \\
18 \cdot 2\end{array}$ & $\begin{array}{r}13 \cdot 0 \\
6 \cdot 0 \\
8 \cdot 5 \\
16 \cdot 7\end{array}$ & $\begin{array}{r}7 \cdot 5 \\
5 \cdot 0 \\
6 \cdot 4 \\
13 \cdot 7\end{array}$ & $\begin{array}{r}8 \cdot 0 \\
2 \cdot 5 \\
5 \cdot 2 \\
14 \cdot 1\end{array}$ \\
\hline $5 \cdot 4(63 \cdot 5)$ & $15 \cdot 0$ & $7 \cdot 5$ & $13 \cdot 0$ & $11 \cdot 8$ & - & $9 \cdot 4$ & $8 \cdot 4$ & Not done \\
\hline $5 \cdot 4(71 \cdot 2)$ & $10 \cdot 0$ & $4 \cdot 0$ & $7 \cdot 8$ & $11 \cdot 0$ & $8 \cdot 0$ & $4 \cdot 0$ & $4 \cdot 0$ & $5 \cdot 2$ \\
\hline $2 \cdot 1(41 \cdot 0)$ & $8 \cdot 5$ & $7 \cdot 9$ & $14 \cdot 0$ & $15 \cdot 6$ & $15 \cdot 8$ & $14 \cdot 5$ & $12 \cdot 5$ & $8 \cdot 7$ \\
\hline $3 \cdot 9(46 \cdot 0)$ & $9 \cdot 0$ & $9 \cdot 0$ & $8 \cdot 1$ & $9 \cdot 8$ & $12 \cdot 2$ & $12 \cdot 0$ & $11 \cdot 9$ & $13 \cdot 1$ \\
\hline
\end{tabular}

ing 24-hour specimens, particularly in family outpatient studies. Plasma and urine were stored at $-15^{\circ} \mathrm{C}$.

Determination of plasma histidine. Plasma was deproteinized with picric acid and the latter removed with an anion exchange resin (Stein and Moore, 1954). The resulting effluent was evaporated to dryness in a rotary evaporator, the deposit dissolved in $10 \%$ isopropanol, and the histidine quantitated by the method of Atfield and Morris (1961). The mean recovery by this method was $96 \%$ when histidine was added to plasma over a range of 1 to $20 \mathrm{mg}$ histidine $/ 100 \mathrm{ml}$.

Analysis of urine. The total histidine content of each 5-hour collection of urine was estimated by the method of Atfield and Morris (1961). Each specimen of urine (or each 5-hour collection when timed urines were impossible) was examined for imidazole compounds. The imidazoles present in a volume of urine equivalent to $0.5 \mathrm{mg}$ creatinine were isolated on an ion exchange resin column, displaced with ammonia, separated by chromatography, and located with Pauly's reagent and ultraviolet light as described by Smith (1969). Imidazole-pyruvic, -lactic and -acetic acids, urocanic acid and $\mathrm{N}$-acetyl histidine were quantitated approximately by visual comparison with standards.

Histidase activity and urocanic acid in skin. The activity of histidine ammonia-lyase (histidase) and the urocanic acid content of skin were determined by the method of Whitfield and Shepherd (1970).

\section{Results of Biochemical Investigations}

In the control adults the mean fasting level of plasma histidine was 1.7 to $3.6 \mathrm{mg} / 100 \mathrm{ml}$. On loading, a peak of 6.0 to $16.8 \mathrm{mg} / 100 \mathrm{ml}$ was recorded after 1 hour but there was a considerable scatter in the values obtained and detailed results are shown in Fig. 1. The mean urinary excretion of histidine during the five hours after the oral load was $4.7 \mathrm{mg} / \mathrm{kg}$ body weight (range 2.5 to $7 \cdot 1$ ). Urinary metabolites were minimal in all the adult controls before and after loading, and a typical result is shown in Table IV.

Plasma histidine levels on the 'control' children could not be estimated at every point in each child owing to a shortage of blood. Detailed results are shown in Fig. 2. The mean fasting value was $2.7 \mathrm{mg} / 100 \mathrm{ml}$ (range 1.3 to $4 \cdot 1$ ). On loading there was a considerable scatter in the values obtained, but the levels in the younger children were perhaps lower than those in the older ones; the data are insufficient for a conclusion. The plasma histidine levels after loads in families 1 and 2 and Case 5, 6, and 7 are shown in Table III. The 
TABLE IV

Urinary Metabolites in Response to a Histidine Load

\begin{tabular}{|c|c|c|c|c|c|c|c|c|c|}
\hline Subject & Histidine* & $\begin{array}{c}\text { Im-pyruvic } \\
\text { acid }^{\star}\end{array}$ & $\underset{\text { acid }^{\star}}{\text { Im-lactic }}$ & $\begin{array}{l}\text { N-acetyl- } \\
\text { histidine* }\end{array}$ & $\begin{array}{c}\text { Im-acetic } \\
\text { Acid* }\end{array}$ & $\begin{array}{l}\text { Urocanic } \\
\text { Acid }^{\star}\end{array}$ & $\begin{array}{l}\text { Unidentified } \\
\text { Metabolite } \\
\text { Blue with } \\
\text { Pauly's } \\
\text { Reagent }\end{array}$ & $\begin{array}{c}\text { Number of } \\
\text { Other } \\
\text { Metabolites } \\
\text { Located with } \\
\text { Pauly's Reagent }\end{array}$ & $\begin{array}{l}\text { Number of } \\
\text { Other } \\
\text { Metabolites } \\
\text { Detected with } \\
\text { UV Light† }\end{array}$ \\
\hline 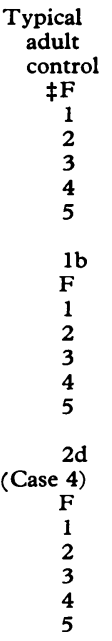 & $\begin{array}{r}100 \\
150 \\
>200 \\
>200 \\
>200 \\
>200\end{array}$ & $\begin{array}{c}\text { Trace } \\
5 \\
\text { Trace } \\
\text { ND } \\
\text { ND } \\
\text { ND } \\
\\
\\
\text { Trace } \\
\text { Trace } \\
5 \\
10 \\
15 \\
25\end{array}$ & $\begin{array}{c}2 \\
2 \\
4 \\
4 \\
2 \\
2 \\
\\
6 \\
6 \\
6 \\
\text { much }>30 \\
\text { much }>30 \\
20 \\
\\
>30 \\
>30 \\
\text { much }>30 \\
\text { much }>30 \\
\text { much }>30 \\
\text { much }>30\end{array}$ & $\begin{array}{l}\text { ND } \\
\text { ND } \\
\text { Trace } \\
\text { Trace } \\
\text { ND } \\
\text { ND } \\
\\
\\
\text { Trace } \\
2 \\
8 \\
20 \\
20 \\
20\end{array}$ & $\begin{array}{c}\text { Trace } \\
1 \\
10 \\
5 \\
2 \\
1 \\
\\
2 \\
3 \\
3 \\
10 \\
10 \\
10\end{array}$ & $\begin{array}{c}\text { Trace } \\
\text { Trace } \\
1 \\
2 \\
1 \\
\text { Trace } \\
\\
\text { Trace } \\
\text { Trace } \\
\text { ND } \\
\text { Trace } \\
\text { Trace } \\
\text { Trace }\end{array}$ & $\begin{array}{c}\text { ND } \\
\text { ND } \\
\text { ND } \\
\text { ND } \\
\text { ND } \\
\text { ND } \\
\\
\text { ND } \\
\text { ND } \\
\text { ND } \\
+ \\
\text { Trace } \\
\text { ND }\end{array}$ & 3 or less & $\begin{array}{l}\text { Not more } \\
\text { than } 2\end{array}$ \\
\hline
\end{tabular}

^Histidine and known metabolites are expressed as $\mu \mathrm{g}$ present in urine equivalent to $0.5 \mathrm{mg}$ creatinine.

† Metabolites which appear or increase in concentration in the $3 \mathrm{hr}$ urine sample compared with the fasting sample.

$\ddagger$ Fasting, and then $1,2,3,4$, and 5 hours after loading. ND, not detected.

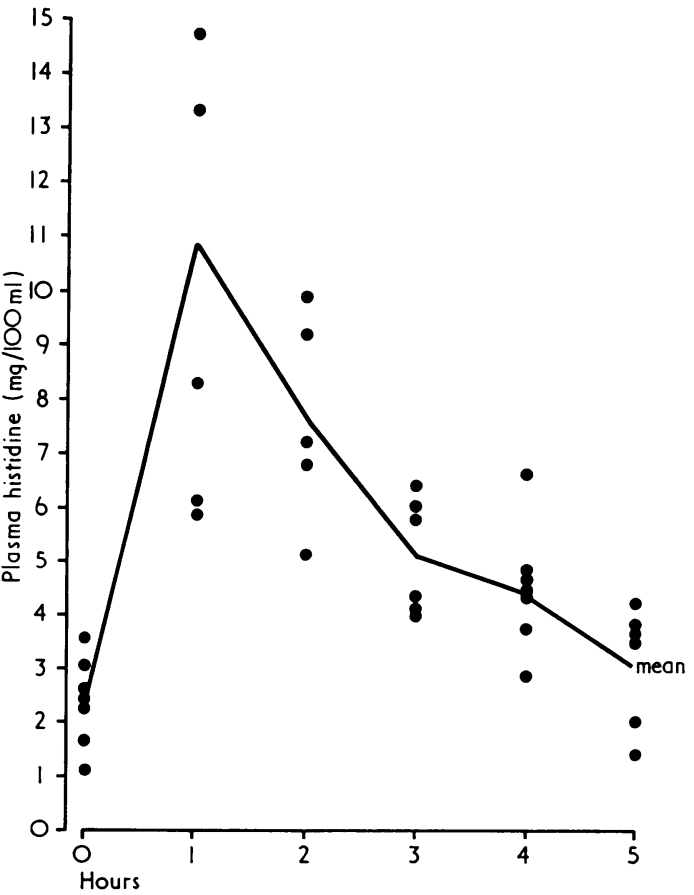

Fig. 1.-Plasma histidine levels in normal adults after a load.

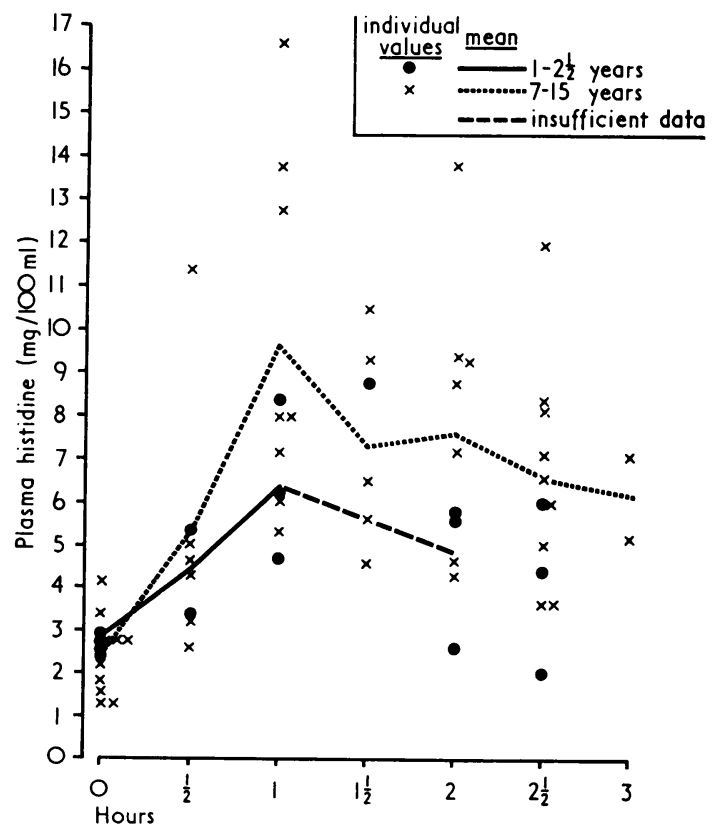

FIG. 2.-Plasma histidine levels in 'control' children following a load 
clearly abnormal responses which occurred in the subjects who had raised fasting levels of histidine are illustrated in Fig. 3. Case 5 was on a low histidine diet when the test was performed and her response was within normal limits. Subjects with raised fasting histidine levels and abnormal tolerances also produced large quantities of imidazole compounds in their urine. Table IV gives details of the urinary metabolites in a typical adult control subject, a typical histidinaemic patient (Case 4), and the most abnormal of the presumed heterozygous parents (1b). The results in the father of Cases 3 and 4 (2a) were less abnormal and those of the mother (2b) were similar to a normal control subject.

Histidase activity and the urocanic acid content of the skin were greatly reduced in all subjects who had raised plasma histidine (see Table III). Parents of index cases had enzyme activity and urocanic acid content in the lower part of the

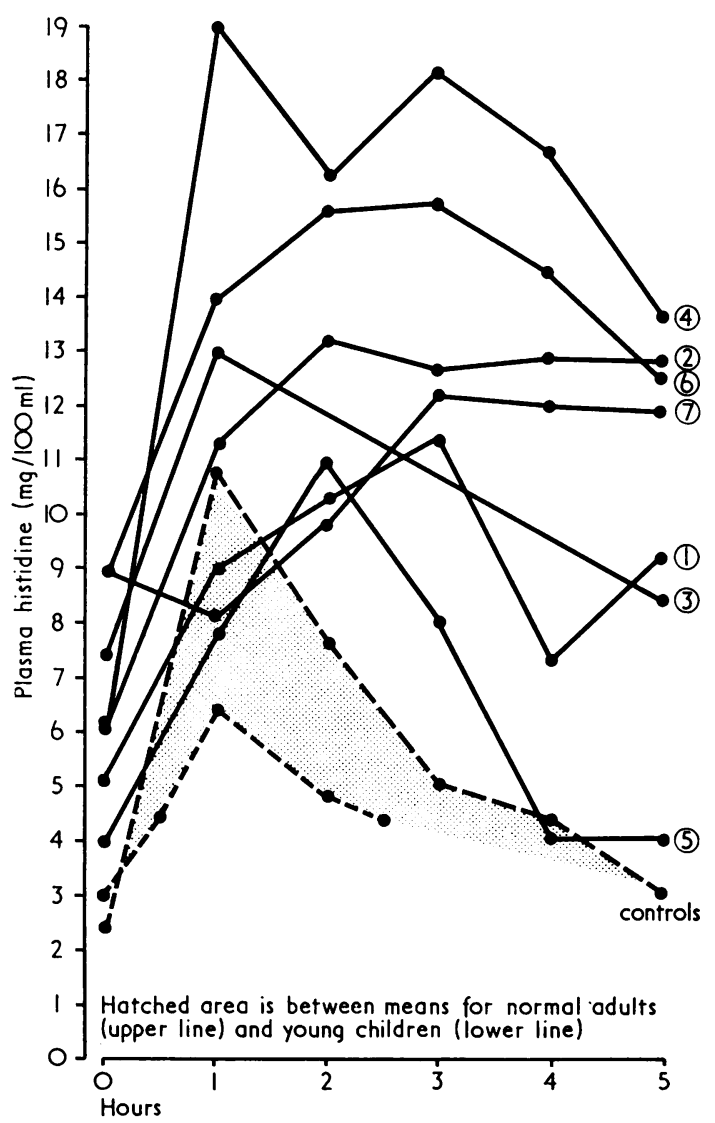

FIG. 3.-Histidine loading tests in subjects with increased fasting plasma histidine levels. control ranges. These determinations also gave somewhat low values in the sibs $1 \mathrm{c}$ and $1 \mathrm{~d}$, and in 2c histidase activity was less than $0.1 \mu$ moles urocanic acid/hr per $\mathrm{g}$ skin though the skin urocanic acid was towards the lower range of normal.

\section{Discussion}

A raised plasma histidine and deficiency of the enzyme histidase (histidinaemia) has usually been discovered during the investigation of mental retardation in the index subject, and then during subsequent investigation of members of his family. Even with this bias to selection the outstanding fact is that over half of those reported with histidinaemia are of normal intelligence. This proportion may perhaps rise now that this abnormality is being detected by screening in the newborn period, particularly if the suggested incidence of 1 in 14,000 births (Levy, 1970) proves correct. The finding of 14 mentally retarded patients with histidinaemia in the past 10 years does not necessarily imply a causal relation and until a prospective study on newborns is available the significance of histidinaemia will remain in doubt.

Of those of average intelligence, 7 out of 28 had immature or retarded speech development, but of these 3 had IQ values at the lower end of the normal range and probably low for their families. Table I also emphasizes the association between seizures, low IQ, and speech problems. Four subjects with speech retardation had been reported by 1963 and in spite of an increasing number of reports on histidinaemia only a further 3 such cases have been discovered. We would therefore agree with recent views against specific speech delay in histidinaemia (Gordon, 1970; Lott et al., 1970). The biased source of these subjects also raises reservations about the minor psychological abnormalities which some workers have reported in apparently normal histidinaemic subjects (Gatfield et al., 1969; Bruckman et al., 1970).

The degree of retardation in the 14 patients in Table II was usually severe. 6 of them had epilepsy and of these, 3 deteriorated neurologically at times of frequent seizures. Case 1 of the present series developed status epilepticus with cerebral oedema during the second week of life, with up to 30 fits a day for about 3 weeks for which no cause was evident. There are no other reports of such an association and her gross retardation and cerebral palsy could well be a consequence of the brain damage incurred at that time. The girl described by Corner et al. (1968) also suffered deterioration during episodes of major seizures and died during 
one of these. A mild but apparently clear intellectual deterioration occurred after the onset of seizures was reported by Gilman and Howell (1969). Though intellectual deterioration is seen in association with severe epilepsy (Norman, 1962) the finding of 3 such patients in a small series is perhaps unusual. In addition the retarded patients with epilepsy were in the main among those with the lowest IQ. Of 28 subjects in Table I with an IQ within the normal range only 3 had major seizures. Two of them with speech retardation and borderline IQ have been discussed already and the third (our Case 6) had major personality problems and psychiatric illness with recurrent depression. Patients with histidinaemia and epilepsy therefore have had additional problems, usually considerable mental retardation. 3 patients with status epilepticus suffered loss of skills at these times and this may be a significant association. No reasons for such an association are suggested.

An association has emerged in 3 of the present patients who showed psychotic disorders of early onset, which in 2 may have followed a respiratory infection. Case 3's early development was slow but after a lower respiratory infection at 1 year his problems of non-communication, aggression, apprehension, repetition, and preoccupation with objects became more obvious. Though he was retarded these features brought him to special notice. There was psychotic regression in Case 5 and development may have been normal up to 21 years when the febrile illness and period of separation occurred. Though the psychotic features in Case 7 may in part have been a consequence of prolonged hospitalization, he seemed to have regressed after an infection at the age of 2 years.

It is unusual to see the onset of a psychotic disorder with clear deterioration in language and cognitive functioning with apparently normal development until 2 years, as in Case 5 and possibly Case 7, which might suggest organic brain disease Though the pathogenesis of early infantile psychotic states remains largely unknown, the importance of neurological disease has been emphasized (Rutter, 1967; Creak, 1963). In the early infantile group there is evidence for an organic association with the disorder, in that severe retardation is frequently present and epilepsy is not uncommon (Rutter et al., 1967). We have seen similar behaviour in some children with treated phenylketonuria, infantile spasms, and leucodystrophies.

The biochemical features of the present subjects show no essential difference from those reported previously. Fasting histidine levels ranged from 5.0 to $9.0 \mathrm{mg} / 100 \mathrm{ml}$ though random levels above
$10 \mathrm{mg} / 100 \mathrm{ml}$ were often found. Using histidine $100 \mathrm{mg} / \mathrm{kg}$ in a 5-hour loading test, the maximum plasma histidine ranged from 11.0 to $19.0 \mathrm{mg} / 100$ $\mathrm{ml}$ after 1 to 3 hours, and the high level was maintained so that the second part of the tolerance was flat. The loading test on Case 5 was within the normal range. This result was unexpected but was performed while she was receiving a low histidine diet. If this is the explanation, it would be in contrast to treated phenylketonuric patients in whom loading tests remain abnormal while on diet (Clayton et al., 1966). The loading tests on normal children taken during Bovril tests are incomplete, but show a tendency to a higher curve in the older ones. Possibly this is related to the fact that histidine appears to be essential in early life and the requirements fall as the child gets older (Snyderman et al., 1963). Skin histidase ranged from a maximum of $0.4 \mu$ moles urocanic acid $/ \mathrm{g}$ skin per hr to undetectable levels, and skin urocanic acid ranged from 0.4 to $12 \mu$ moles/g skin per $\mathrm{hr}$ with no overlap with controls.

Clear separation of parents as presumed heterozygotes from normal controls was not achieved by any single parameter. Skin histidase and urocanic gave low normal or low results (Whitfield and Shepherd, 1970) and fasting plasma histidine, histidine loading, and the appearance of metabolites in the urine were in individual cases abnormal. However, with the limited data at present available, the carrier status of an individual may remain uncertain using all the above techniques. The tests on sibs in the present study illustrate this well. 1c and 1d had low skin histidine activity, marginally reduced skin urocanic acid levels, and normal fasting histidine and histidine loading tests. 2c had a very low skin histidase in the homozygote range and low urocanic acid level but only a marginally abnormal histidine loading test and normal fasting histidine. Probably $1 \mathrm{c}, 1 \mathrm{~d}$, and $2 c$ are all heterozygotes but scatter of results makes this assessment difficult.

The mode of inheritance in the present families would be compatible with autosomal recessive. In the family reported by Bruckman et al. (1970), a woman (AI-11) and 3 of her offspring of a sibship of 6 had histidinaemia. Dominant inheritance was suggested by the authors since the father (AI-10) showed no increase in serum and urinary concentrations of histidine and a FIGLU test was normal. His skin histidase was only $1.4 \mu$ moles urocanic acid/hr per $\mathrm{g}$ skin (lower limit of normal, $1.5)$ and skin urocanic acid was not measured. It seems possible that he may have been heterozygous for histidinaemia, particularly since the 
mother's sister probably had histidinaemia, and raised plasma histidine was not found in any of 7 of her offspring who were partially investigated. Dominant inheritance therefore is unlikely.

The relevance of histidinaemia to the neurological problems and mental functioning of some subjects remains obscure. No biochemical difference between retarded subjects and those of normal intelligence is evident, and their frequent coexistence in one family would be against a genetic explanation of this phenomenon. The important postnatal factors appear to be infection and epilepsy, but their relation to histidinaemia is not clear. Early detection and careful follow-up of infants may help to elucidate this problem, but at present it remains possible that the neurological problems are only a chance association.

Dietary treatment was instituted in Cases 1, 3, and 5 and adequate control was achieved. No dramatic change occurred, but improvement in Case 1 was noted. A full account of the dietary treatment will be published separately. It is difficult to decide whether or not a neonate with the biochemical features of histidinaemia should be given a low diet in histidine, since it is possible that many such cases discovered by newborn screening will have normal development without any treatment. Not only is the significance of a raised plasma histidine in doubt, but synthetic diets in infancy are potentially dangerous. There seems little justification for the use of a diet in infancy at this stage, and it is suggested that careful follow-up of neonates with biochemical histidinaemia is required. Alternatively, a controlled trial of dietary treatment of otherwise normal babies may be justified, though if development appears to be lagging or seizures occurred it might be difficult to withhold the diet.

We thank the following physicians for permission to study patients under their care: Professor $\mathrm{O}$. $\mathrm{H}$. Wolff and Dr. J. Wilson, The Hospital for Sick Children, Great Ormond Street; Dr. Beatrice Crocket and Dr. Lynch, Royal Eastern Counties Hospital, Colchester, and Mr. Steven Dorner and Mr. David Buick who carried out psychological testing on families 1 and 2 . We are grateful for financial assistance from The Wellcome Trust, the Medical Research Council, and the Joint Research Board of The Hospital for Sick Children and Institute of Child Health. Part of this work was carried out while one of us (B.G.R.N.) held an appointment of Academic Registrar, Institute of Neurology, Queen Square.

\section{REFERENCES}

Atfield, G. N., and Morris, C. J. O. R. (1961). Analytical separations by high-voltage electrophoresis: amino acids in protein hydrolysates. Biochemical fournal, 81, 606.
Auerbach, V. H., DiGeorge, A. M., Baldridge, R. C., Tourtellotte, C. D., and Brigham, M. P. (1962). Histidinemia: a deficiency in histidase resulting in the urinary excretion of histidine and of imidazolepyruvic acid. Fournal of Pediatrics, 60, 487.

Auerbach, V. H., DiGeorge, A. M., and Carpenter, G. G. (1967). Histidinemia. In Amino Acid Metabolism and Genetic Variation, p. 145. Ed. by W. L. Nyhan. Blakiston, New York.

Bruckman, C., Berry, H. K., and Dasenbrock, R. J. (1970). Histidinemia in two successive generations. American fournal of Diseases of Children, 119, 221.

Cain, A. R. R., and Holton, J. B. (1968). Histidinaemia: a child and his family. Archives of Disease in Childhood, 43, 62.

Clarance, G. A., and Bowman, J. K. (1966). Further case of histidinaemia. British Medical fournal, 1, 1019.

Clayton, B. E., Moncreiff, A. A., Pampiglione, G., and Shepherd, J. (1966). Biochemical and EEG studies in phenylketonuric children during phenylalanine tolerance tests. Archives of Disease in Childhood, 41, 267.

Corner, B. D., Holton, J. B., Norman, R. M., and Williams, P. M. (1968). A case of histidinemia controlled with a low histidine diet. Pediatrics, 41, 1074.

Creak, E. M. (1963). Childhood psychosis: a review of 100 cases. British Fournal of Psychiatry, 109, 84.

Davies, H. E., and Robinson. M. J. (1963). A case of histidinaemia. Archives of Disease in Childhood, 38, 80.

Gatfield, P. D., Knights, R. M., Devereux, M., and Pozsonyi, J. P. (1969). Histidinemia: report of four new cases in one family and the effect of low-histidine diets. Canadian Medical Association fournal, 101, 465.

Gerritsen, T. (1964). Histidinaemia and mental retardation. Proceedings of the International Copenhagen Conference on the Scientific Study of Mental Retardation, vol. 1, p. 94 . Ed. by J. Øster. Copenhagen Danish National Society of the Mentally Retarded, Copenhagen.

Ghadimi. H., Partington, M. W., and Hunter, A. (1961). A familial disturbance of histidine metabolism. New England fournal of Medicine, 265, 221.

Ghadimi, H., Partington, M. W., and Hunter, A. (1962). Inborn error of histidine metabolism. Pediatrics, 29, 714.

Gilman, P. A., and Howell, R. R. (1969). The simultaneous occurrence of histidinemia and congenital hypoplastic anemia. Fournal of Pediatrics, 75, 878.

Gordon, N. (1970). Delayed speech and histidinaemia. Developmental Medicine and Child Neurology, 12, 104

Jackson, D., Grant, D. B., and Clayton, B. E. (1968). A simple oral test of growth-hormone secretion in children. Lancet, 2 , 373.

La Du, B. N. (1966). Histidinemia. In The Metabolic Basis of Inherited Disease, 2nd ed., p. 366. Ed. by J. B. Stanbury, J. B. Wyngaarden, and D. S. Fredrickson. McGraw-Hill, New York.

La Du, B. N., Howell, R. R., Jacoby, G. A., Seegmiller, J. E., Sober, E. K., Zannoni, V. G., Canby, J. P., and Ziegler, L. K. (1963). Clinical and biochemical studies on two cases of histidinemia. Pediatrics, 32, 216.

Levy, H. L. (1970). Biochemical detection of genetic diseases. Paper read at the Fogerty International Conference on Ethical Problems in Human Genetics. National Institutes of Health, Bethesda, Maryland.

Lott, I. T., Wheelden, J. A., and Levy, H. L. (1970). Speech and histidinemia: methodology and evaluation of four cases. Developmental Medicine and Child Neurology, 12, 596.

Neville, B. G. R., Harris, R. F., Stern, D. J., and Stern, J. (1971). Maternal histidinaemia. Archives of Disease in Childhood, 46, 119.

Norman, R. M. (1962). Neuropathological findings in acute hemiplegia in childhood, with special reference to epilepsy as a pathogenic factor. In Acute Hemiplegia in Childhood (Little Club Clinics in Developmental Medicine, No. 6), p. 37. Ed. by M. Bax and R. Mitchell. Heinemann, London.

Rosenblatt, D., Mohyuddin, F., and Scriver, C. R. (1970). Histidinemia discovered by urine screening after renal transplantation. Pediatrics, 46, 47.

Rutter, M. (1967). Psychotic disorders in early childhood. British fournal of Psychiatry, 113, Suppl., 133.

Rutter, M., Greenfield, D., and Lockyer, L. (1967). A five to fifteen year follow-up study of infantile psychosis II. Social and behavioural outcome. British fournal of Psychiatry, 113, 1183. 
Shaw, K. F. N., Boder, E., Gutenstein, M., and Jacobs, E. E. (1963). Histidinemia. Fournal of Pediatrics, 63, 720.

Smith, I. (1969). Imidazoles: location reagents. In Chromatographic and Electrophoretic Techniques, 3rd ed., Vol. 1, p. 274. Ed. by I. Smith. Heinemann, London.

Snyderman, S. E., Boyer, A., Roitman, E., Holt, L. E., Jr., and Prose, P. H. (1963). The histidine requirement of the infant. Pediatrics, 31, 786.

Stein, W. H., and Moore, S. (1954). The free amino acids of human blood plasma. Fournal of Biological Chemistry, 211, 915.
Wadman, S. K., van Sprang, F. J., van Stekelenburg, G. J., and de Bree, P. K. (1967). Three new cases of histidinemia. Acta Paediatrica Scandinavica, 56, 485.

Whitfield, A. E., and Shepherd, J. (1970). Measurement of L-histidine ammonia-lyase activity and urocanic acid content of human skin. Clinica Chimica Acta, 29, 181.

Woody, N. C., Snyder, C. H., and Harris, J. A. (1965). Histidinemia. American fournal of Diseases of Children, 110, 606.

Correspondence to Dr. B. E. Clayton, The Hospital for Sick Children, Great Ormond Street, London WC1. 